\title{
ORIGINAL
}

\section{A Study on Natural Absorbed Dose Rate in Air (Using TLDs) and Concentration of Natural Radionuclides in Soil in All Area of the Osaka Pref.}

\author{
Kazuko Megumi, ${ }^{*}{ }^{* 1}$ Masahiro DoI, ${ }^{* *, * 3}$ Takashi OKa, ${ }^{* *}, * 2$ \\ Tadao MATSUnAmI ${ }^{* * * *, * 1}$ and Toshio ISHIYAMA $* * * * * * 1$
}

(Received October 8, 1990)

(Accepted February 7, 1991)

\begin{abstract}
Absurbed dose rates in air at 40 sites throughout Osaka Pref. were measured by TLDs and a relationship between the dose rates and the rates estimated from concentrations of natural radionuclides in the surface soils collected at the sites was studied. The highest and lowest values of air absorbed dose rates obtained in Osaka Pref. were $114.1 \pm 1.0,66.3 \pm 2.3 \mathrm{nGy} / \mathrm{h}$, respectively, and the former value was obtained at granite zone and the latter at andesite zone. It was found that soil particles smaller than 10 mesh contribute to the dose rates more significantly than those larger than $10 \mathrm{mesh}$. We found a fairly good correlation between the dose rates and the concentrations of ${ }^{40} \mathrm{~K}$ in the surface soils at the sites.
\end{abstract}

KEY WORDS: absorbed dose rate in air, TLD, Osaka, soil, concentration of natural radionuclides, mineral composition, 10 mesh

\section{INTRODUCTION}

Knowledge on the natural absorbed dose rate

* 恵 和子, ** 土居雅広, $* * *$ 岡 喬, **** 松並忠男, ****** 石山稔雄

*1 Research Center of Radioisotopes, Research institute for Advanced Science and Technology, University of Osaka Prefecture; Sakai City, Osaka 593

大阪府立大学附属研究所, アイントープ総合研究センタ 一; 堺市新家町 174-16 (

*2 Research Center of Radiation, Research Institute for Advanced Science and Technology, University of Osaka Prefecture; Sakai City, Osaka 593 大阪府立大学附属研究所, 放射線科学研究センター; 界 市新家町 174-16 (T593)

*3 Present Address: National Institute of Radiological Sciences; 9-1, Anagawa 4-chome, Chiba 260.

現在 : 放射線医学総合研究所 ; 千葉市穴川 4-9-1 (宁280) in air is important for an individual and the public from a viewpoint of health physics. An evaluation of practical relationships between the dose rate and the concentration of natural radionuclides in surface soil is useful in estimating easily the dose rate from the concentrations of the nuclides in the surface soil of small amount.

The Osaka Prefecture in October of 1989 had a population of $8,747,000$ which is about $7 \%$ of the total Japanese population of $123,255,000$ and this population is the largest next to the Tokyo metropolitan area. According to field survey data of natural radiation in Japan obtained by S. ABE et al. ${ }^{1-3)}$, the dose level in Osaka is about 1.5 times higher than each level in the Tokyo Metropolis, the Kanagawa Pref. and the Chiba Pref. This is due to the fact that the Kansai area including Osaka is composed of granitic zone containing a higher concentrations of natural radionuclides in comparison with other geological 


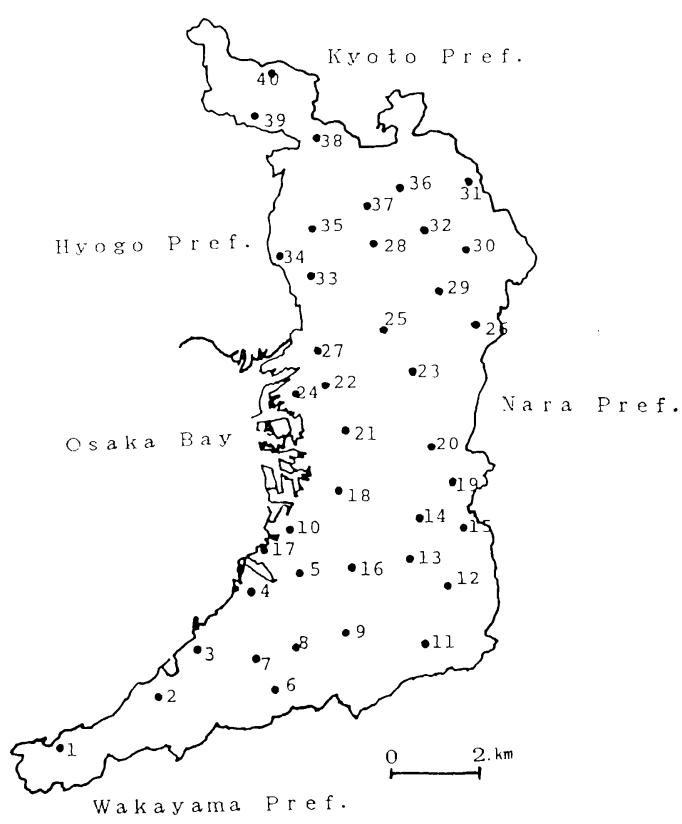

Fig. 1 A map showing the locations of the monitoring posts.

zones $^{3-7)}$ while the Kanto area including Tokyo is in volcanic ash zone. The exact determination of the population-weighted annual collective dose based on more measurements than that $\mathrm{ABE}$ et al. had done in Osaka Pref. ${ }^{1)}$ is important to obtain national collective dose in Japan. The Osaka Pref. mainly consists of granitic mountains on the east and the south sides and a wide alluvial plain in the center. The understanding of distributions of the dose rate due to geological conditions is fundamentally significant.

This paper describes the outdoor air absorbed dose rates measured at 40 sites by thermoluminescence dosimeters (TLDs), and relationships between the measured dose rates and the dose rate estimated by concentrations of U-series, Thseries and ${ }^{40} \mathrm{~K}$. Also measured were mineral compositions in the soil samples collected on the sites. The authors would suggest a simple method to estimate the dose rates based on the concentration of ${ }^{40} \mathrm{~K}$ in soil samples.

\section{EXPERIMENT}

\section{Allotment of site}

A total of 40 sites was selected to measure the absorbed dose rates in air in the Osaka Pref., as

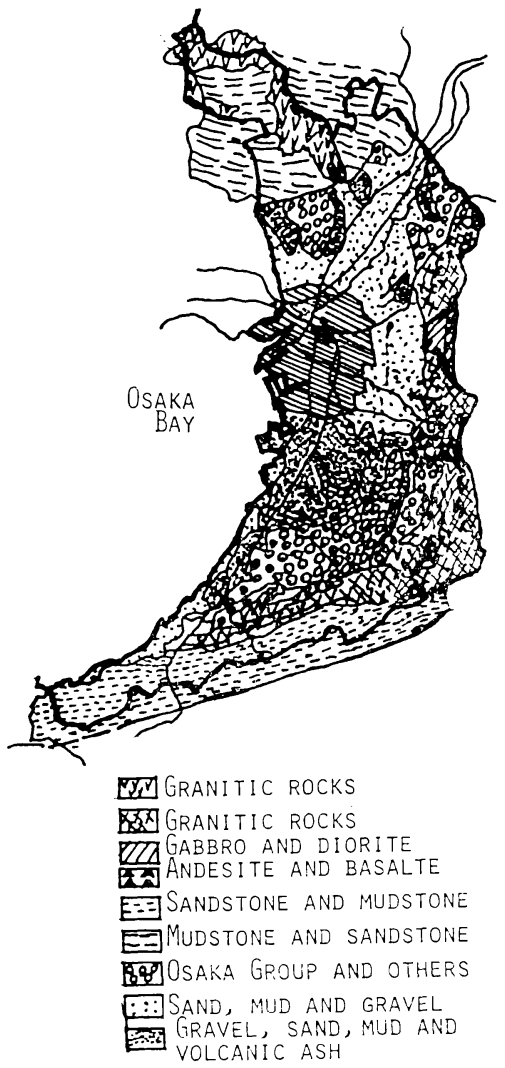

Fig. 2 A geological map of Osaka Pref.

shown in Fig. 1 and Table 1, in relation to geology, administrative boundary and population density. We alloted corners of playgrounds in 25 schools for the sites. The area of Osaka Pref. is 1866.86 $\mathrm{km}^{2}$. Ryouke granitic and andesite mountains are located at the east and south sides of Osaka Pref. as shown in Fig. 2. The Osaka Pref. consists of Osaka city with a population of $2,000,000$ and several satellite cities with a total population of several hundred thousands.

\section{Absorbed dose rate in air}

The TLD used in this study was a dosimeter containing two calcium sulfate chips. ${ }^{8}$ ) Two sets of TLDs were put in a wooden box which were $1.2 \mathrm{~m}$ above the ground, and were kept at the sites for two months. The absorbed dose rates in air were obtained by averaging data of three cycles at same sites. Then, each absorbed dose rate in air is the mean over six months. The authors measured the absorbed dose rates in air at two sites for two years and noticed no seasonal effect. This may be caused by mild climate. In 
Table 1 Sites where the absorbed dose rate in air and the concentration of radionuclides of soil were measured.

\begin{tabular}{|c|c|}
\hline Site No. & Name of sites measured \\
\hline 1 & Osaka Prefectural Misaki High School \\
\hline 2 & Osaka Prefectural Sunagawa High School \\
\hline 3 & Osaka Prefectural Sano High School \\
\hline 4 & Osaka Prefectural Kishiwada High School \\
\hline 5 & Osaka Prefectural Shinoda High School \\
\hline 6 & Kaizuka City Sohara Primary School \\
\hline 7 & Kaizuka City Third Junior High School \\
\hline 8 & Kishiwada City Higashikatsuragi Primary School \\
\hline 9 & Izumi City Makio Junior High School \\
\hline 10 & Hagoromo Gakuen High School \\
\hline 11 & Kawachi-Nagano City Takihata Primary School \\
\hline 12 & Chihaya Akasaka Village Junior High School \\
\hline 13 & Prefectural Tondabayashi Public Health Center \\
\hline 14 & Prefectural Habikino Hospital \\
\hline 15 & Minamikawachi County Taishi cho Taishi Junior High School \\
\hline 16 & Pool Gakuin College \\
\hline 17 & Osaka Prefectural Izumiootsu Public Health Center \\
\hline 18 & Kinki Central Hospital \\
\hline 19 & Osaka Prefectural Shuutokugakuin \\
\hline 20 & Osaka Prefectural Yao Public Health Center \\
\hline 21 & Osaka Prefectural Tennouji High School \\
\hline 22 & Osaka Castle \\
\hline 23 & Kawamata Water Disposa! Plant \\
\hline 24 & Osaka Prefectural Ichioka High School \\
\hline 25 & Osaka Prefectural Moriguchi High School \\
\hline 26 & Shijyounawate City Shijyonawate Minami Junior High School \\
\hline 27 & Osaka Prefectural Kitano High School \\
\hline 28 & Osaka Prefectural Kasugaoka High School \\
\hline 29 & Neyagawa City Kunimatsu Primary School \\
\hline 30 & Osaka Prefectural Murano Water Purification Plant \\
\hline 31 & Osaka Prefectural Youth Recreation Center \\
\hline 32 & Osaka Prefectural Takatsuki Minami High School \\
\hline 33 & Osaka Prefectural Toyonaka Public Health Center \\
\hline 34 & Osaka Prefectural Gardening High School \\
\hline 35 & Minoo City Minoo Water Purification Plant \\
\hline 36 & Health Center for Physically Handicapped Children \\
\hline 37 & Osaka Prefectural Fukui High School \\
\hline 38 & Osaka Prefectural Shiroyama High School \\
\hline 39 & Osaka Prefectural Ranch \\
\hline 40 & Osaka Prefectural Youth Field Exercise Center \\
\hline
\end{tabular}


order to eliminate unreliable sub-peak values and exclude fading in TLDs, the authors carried out preannealing of TLDs at $100^{\circ} \mathrm{C}$ for $4 \mathrm{~min}$ before reading the values as described in our paper. ${ }^{9}{ }^{\text {) }}$ The TLDs were calibrated by irradiating 87.3 $\mu$ Gy using ${ }^{226} \mathrm{Ra}$ and ${ }^{137} \mathrm{Cs}$ standard sources. We divided the whole of the Osaka Pref. into four sections and spent three years measuring the absorbed dose rates in air at all 40 sites.

3. Concentration of radionuclides and mineral composition

We collected soil samples of $5 \mathrm{~cm}$ thick core from surface of the ground to $10 \mathrm{~cm}$ or $30 \mathrm{~cm}$ depth by using an iron core sampler which is $9.5 \mathrm{~cm}$ in diameter and $30 \mathrm{~cm}$ in height. Each core sample of $5 \mathrm{~cm}$ thick was dried in air for several days and at $105^{\circ} \mathrm{C}$ in an oven for several hours and was sieved into two classes of particle sizes by using a standard sieve of 10 mesh. Soil particles smaller than 10 mesh were measured in that condition, but those larger than 10 mesh were crushed before their activities were measured. Each soil sample of $120 \mathrm{~g}$ was sealed into a polyvinyl chlorides case. Then each specimen was subjected to gamma-ray spectrometry with a planer type of Ge detector and a coaxial type of $\mathrm{Ge}(\mathrm{Li})$ detector. To reduce the background counting, the planer type of detector was surrounded with lead, brass and cadmium and the coaxial type of detector was placed in an iron shield with lead and polyvinyl chloride lining. ${ }^{10}$ The activities of ${ }^{238} \mathrm{U},{ }^{226} \mathrm{Ra},{ }^{228} \mathrm{Ra}$ and ${ }^{40} \mathrm{~K}$ were determined by the $63.3 \mathrm{keV}$ gamma-rays of ${ }^{23} \mathrm{Th}$, the $609 \mathrm{keV}$ gamma-rays of ${ }^{214} \mathrm{Bi}$, the $583 \mathrm{keV}$ gamma-rays of ${ }^{208} \mathrm{Tl}$ and its $1.46 \mathrm{MeV}$ gammarays, respectively. The authors used reference samples of NBL (the New Brunswick Laboratory of the Atomic Energy Commission) as a standard for the activity determination. In order to determine the mineral composition, each dried sample after desegregated in an agate mortar was subjected to X-ray diffraction analysis performed by using copper radiation and nickel filter.

\section{Water content ratio}

Water content ratio is a percentage value of net weight loss of a sample by drying divided by weight of fresh soil sample. Every fresh soil was kept sealed in a polyvinyl bag immediately after collecting and was weighed at first. The samples dried at $105^{\circ} \mathrm{C}$ as described above were weighed at second and, thus, the water content ratios were
Table 2 Dose rates in Osaka Pref.

\begin{tabular}{|c|c|c|c|}
\hline $\begin{array}{c}\text { Site } \\
\text { number }\end{array}$ & $\begin{array}{c}\text { Absorbed } \\
\text { dose rate } \\
\text { in air } \\
n G y / h\end{array}$ & $\begin{array}{c}\text { Exposure } \\
\text { rate } \\
\mu \mathrm{R} / \mathrm{h}\end{array}$ & $\begin{array}{c}\text { Annual } \\
\text { efrective dose } \\
\text { equivalent } \\
\mathrm{mSv} / \mathrm{y}\end{array}$ \\
\hline 1 & $81.0 \pm 0.3$ & $9.28 \pm 0.03$ & $0.67 \pm 0.01$ \\
\hline 2 & $94.4 \pm 8.6$ & $10.81 \pm 0.98$ & $0.76 \pm 0.01$ \\
\hline 3 & $73.2 \pm 1.7$ & $8.38 \pm 0.20$ & $0.61 \pm 0.00$ \\
\hline 4 & $81.0 \pm 2.4$ & $9.28 \pm 0.27$ & $0.67 \pm 0.00$ \\
\hline 5 & $97.3 \pm 1.2$ & $11.14 \pm 0.14$ & $0.79 \pm 0.00$ \\
\hline 6 & $85.8 \pm 2.1$ & $9.83 \pm 0.24$ & $0.70 \pm 0.00$ \\
\hline 7 & $80.0 \pm 1.8$ & $9.16 \pm 0.21$ & $0.66 \pm 0.00$ \\
\hline 8 & $104.1 \pm 2.7$ & $11.93 \pm 0.31$ & $0.83 \pm 0.00$ \\
\hline 9 & $90.4 \pm 2.1$ & $10.35 \pm 0.24$ & $0.74 \pm 0.00$ \\
\hline 10 & $85.5 \pm 2.0$ & $9.79 \pm 0.23$ & $0.70 \pm 0.00$ \\
\hline 11 & $114.1 \pm 1.0$ & $13.07 \pm 0.11$ & $0.91 \pm 0.00$ \\
\hline 12 & $67.0 \pm 1.9$ & $7.68 \pm 0.22$ & $0.57 \pm 0.00$ \\
\hline 13 & $69.1 \pm 1.0$ & $7.92 \pm 0.12$ & $0.58 \pm 0.00$ \\
\hline 14 & $75.9 \pm 2.7$ & $8.69 \pm 0.31$ & $0.63 \pm 0.00$ \\
\hline 15 & $66.3 \pm 2.3$ & $7.60 \pm 0.26$ & $0.56 \pm 0.00$ \\
\hline 16 & $80.6 \pm 2.7$ & $9.23 \pm 0.31$ & $0.67 \pm 0.00$ \\
\hline 17 & $79.7 \pm 2.4$ & $9.13 \pm 0.27$ & $0.66 \pm 0.00$ \\
\hline 18 & $74.0 \pm 1.8$ & $8.48 \pm 0.21$ & $0.62 \pm 0.00$ \\
\hline 19 & $69.0 \pm 2.7$ & $7.90 \pm 0.31$ & $0.58 \pm 0.00$ \\
\hline 20 & $71.5 \pm 2.1$ & $8.19 \pm 0.24$ & $0.60 \pm 0.00$ \\
\hline 21 & $72.5 \pm 1.6$ & $8.30 \pm 0.18$ & $0.61 \pm 0.00$ \\
\hline 22 & $79.8 \pm 2.4$ & $9.14 \pm 0.27$ & $0.66 \pm 0.00$ \\
\hline 23 & $85.3 \pm 0.3$ & $9.77 \pm 0.03$ & $0.70 \pm 0.01$ \\
\hline 24 & $84.6 \pm 1.4$ & $9.69 \pm 0.16$ & $0.69 \pm 0.00$ \\
\hline 25 & $90.4 \pm 1.7$ & $10.36 \pm 0.20$ & $0.74 \pm 0.00$ \\
\hline 26 & $89.5 \pm 2.2$ & $10.25 \pm 0.25$ & $0.73 \pm 0.00$ \\
\hline 27 & $81.7 \pm 1.2$ & $9.36 \pm 0.14$ & $0.67 \pm 0.00$ \\
\hline 28 & $82.5 \pm 3.0$ & $9.45 \div 0.34$ & $0.68 \pm 0.00$ \\
\hline 29 & $81.3 \pm 1.8$ & $9.31 \pm 0.21$ & $0.67 \pm 0.00$ \\
\hline 30 & $88.3 \pm 2.2$ & $10.12 \pm 0.25$ & $0.72 \pm 0.00$ \\
\hline 31 & $90.5 \pm 1.7$ & $10.37 \pm 0.20$ & $0.74 \pm 0.00$ \\
\hline 32 & $108.3 \pm 1.9$ & $12.40 \pm 0.22$ & $0.86 \pm 0.00$ \\
\hline 33 & $89.9 \pm 1.5$ & $10.30 \pm 0.17$ & $0.73 \pm 0.00$ \\
\hline 34 & $75.6 \pm 1.3$ & $8.66 \pm 0.15$ & $0.63 \pm 0.00$ \\
\hline 35 & $85.8 \pm 1.3$ & $9.83 \pm 0.15$ & $0.70 \pm 0.00$ \\
\hline 36 & $80.3 \pm 0.9$ & $9.20 \pm 0.11$ & $0.66 \pm 0.00$ \\
\hline 37 & $96.6 \pm 1.2$ & $11.07 \pm 0.14$ & $0.78 \pm 0.00$ \\
\hline 38 & $80.9 \pm 1.4$ & $9.27 \pm 0.16$ & $0.67 \pm 0.00$ \\
\hline 39 & $79.4 \pm 1.7$ & $9.10 \pm 0.20$ & $0.66 \pm 0.00$ \\
\hline 40 & $101.5 \pm 1.3$ & $11.63 \pm 0.15$ & $0.82 \pm 0.00$ \\
\hline
\end{tabular}


Table 3 Relationship between the main mineral compositions of the soils collected at 40 sites and the absorbed dose rates in air.

\begin{tabular}{|c|c|c|c|}
\hline Group & Main mineral compositions & Site number & $\begin{array}{l}\text { Absorbed } \\
\text { dose rates } \\
\text { in air } \\
n G y / h\end{array}$ \\
\hline (A) & quartz, feldspar, mica, amphibole & $\begin{array}{l}2,5,6,8,9,10,11,23,24,25, \\
26,27,29,30,31,32,33,37,40\end{array}$ & $81-115$ \\
\hline (B) & quartz, (feldspar) & $\begin{array}{l}1,3,4,7,18,21,22,28,35,36, \\
39\end{array}$ & $72-86$ \\
\hline (C) & $\begin{array}{l}\text { quartz, kaolinite, mica, amphibole, (feldspar, } \\
\text { chlorite) }\end{array}$ & $\begin{array}{l}12,13,14,15,16,17,19,20,34, \\
38\end{array}$ & $66-81$ \\
\hline
\end{tabular}

Table 4 Dose rates in Osaka Pref.

The highest absorbed dose rate in air

The lowest absorbed dose rate in air

The central value of absorbed dose rate in air

The mean value of absorbed dose rate in air

Annual collective dose

$$
\begin{array}{r}
114.1 \pm 1.0 \mathrm{nGy} / \mathrm{h} \\
66.3 \pm 2.3 \mathrm{nGy} / \mathrm{h} \\
81.0 \pm 2.4 \mathrm{nGy} / \mathrm{h} \\
84.1 \pm 0.4 \mathrm{nGy} / \mathrm{h} \\
5,198 \mathrm{man} \cdot \mathrm{Sv} / \mathrm{y}
\end{array}
$$

determined.

\section{RESULTS AND DISCUSSION}

Table 2 shows the air absorbed dose rates obtained by TLDs at all the 40 sites. Figure 3 shows its frequency distribution. The soil particles smaller than 10 mesh collected at the 40 sites had mineral compositions as shown in Table 3. The soil samples were classified into groups of (A)-(C) as shown in Table 3. The group (A) is mainly composed of soils originated from weathering of granite and the group (B) consists of alluvial soil. The group (C) is mainly composed of soils of Osaka group, andesite and basalts. Some samples of the (B) and (C) groups contain small amount of calcites. We obtained the highest value at the granite zone and the lowest value at the andesite zone as shown in Table 4. T. Tsujimoto et al. ${ }^{11)}$ had determined air dose rates by an ionization chamber at the granitic zone as 12.0-14.2 $\mu \mathrm{R} / \mathrm{h}$ $(105-124 \mathrm{nGy} / \mathrm{h})$, at the Osaka group as 6.8-9.7 $\mu \mathrm{R} / \mathrm{h}(60-84 \mathrm{nGy} / \mathrm{h})$ and at the alluvial zone as 8.5-10.7 $\mu \mathrm{R} / \mathrm{h}(74-94 \mathrm{nGy} / \mathrm{h})$ in the Osaka Pref. The air absorbed dose rate obtained by our TLD measurements agree with the values of Tsuлгмото et al. The absorbed dose rates in air at $1.2 \mathrm{~m}$ above the ground surface are given by the con-

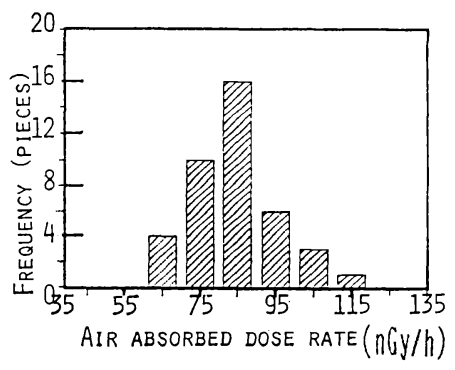

Fig. 3 Frequency of the air absorbed dose rate measured by TLDs at 40 sites in Osaka Pref.

centrations of ${ }^{238} \mathrm{U},{ }^{232} \mathrm{Th}$ and ${ }^{40} \mathrm{~K}$ in soil according to Eq. (1) ${ }^{12}$ as described below; the calculations are based on the assumption that all decay products of ${ }^{238} \mathrm{U}$ and ${ }^{232} \mathrm{Th}$ are in radioactive equilibrium with their precursors. Open circles in Fig. 4 show a relation between the air absorbed dose rates obtained by the TLD measurements (30 $\mathrm{nGy} / \mathrm{h}$ is subtracted as cosmic radiation contribution) and the dose rates calculated by Eq. (1) ${ }^{12}$ ) from the concentrations of ${ }^{238} \mathrm{U},{ }^{228} \mathrm{Ra}$ and ${ }^{40} \mathrm{~K}$ in wet soil samples smaller than 10 mesh.

$$
D=0.044 \times K+0.47 \times U+0.63 \times T h
$$

$D$ : absorbed dose rate in air $1 \mathrm{~m}$ above the ground $(\mathrm{nGy} / \mathrm{h})$

$K$ : concentration of ${ }^{40} \mathrm{~K}$ in wet soil $(\mathrm{Bq} / \mathrm{kg})$

$U$ : concentration of ${ }^{238} \mathrm{U}$ in wet soil $(\mathrm{Bq} / \mathrm{kg})$ 


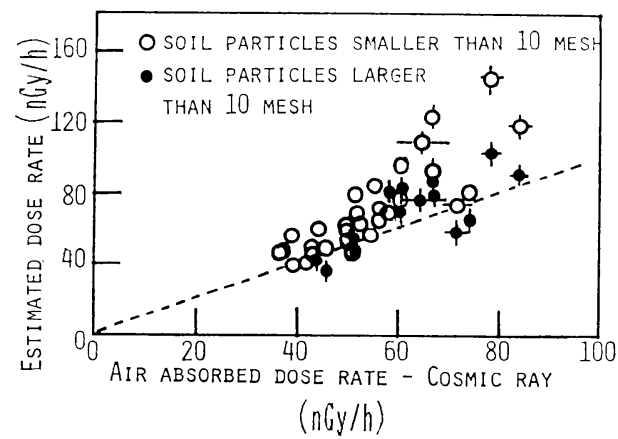

Fig. 4 The relation between the air absorbed dose rates obtained by subtracting cosmic radiation from the dose rates of TLDs measurements and those estimated by Eq. (1) from the concentrations of ${ }^{238} \mathrm{U},{ }^{228} \mathrm{Ra}$ and ${ }^{49} \mathrm{~K}$ in samples smaller $(\bigcirc)$ and larger $(\bullet)$ than 10 mesh.

$T h$ : concentration of ${ }^{232} \mathrm{Th}$ in wet soil $(\mathrm{Bq} / \mathrm{kg})$ We measured the concentrations of these three radionuclides in dried soil samples and then convarted the concentrations into those per unit weight of wet soils by the use of the water content ratio of fresh soil. The dose rates estimated from soil activities are higher than those obtained by TLDs. Closed circles show the similar correlation in the case of soil particles larger than 10 mesh. The values of closed circles are slightly smaller than the values of open circles. This can be explained by the fact shown in Fig. 5. Figure 5 shows a correlation between the concentrations of ${ }^{40} \mathrm{~K}$ and ${ }^{228} \mathrm{Ra}$ in soils smaller than 10 mesh and that in soils larger than 10 mesh. Concentrations of ${ }^{40} \mathrm{~K}$ in soils larger than 10 mesh are higher than those in soils smaller than 10 mesh. On the contrary, the concentrations of ${ }^{238} \mathrm{U}$, ${ }^{226} \mathrm{Ra}$ and ${ }^{228} \mathrm{Ra}$ in soils larger than 10 mesh are lower than those in soils smaller than 10 mesh. The reasons are as follows. As described in our previous paper, ${ }^{13}$ ) for homologous soils resulting from progressive weathering, ${ }^{238} \mathrm{U},{ }^{226} \mathrm{Ra}$ and ${ }^{228} \mathrm{Ra}$ contents increase with an increase of surface area of soils as some of these nuclides are adsorbed on the surface area. However, ${ }^{40} \mathrm{~K}$ contents decrease with an increase of surface area of soil as some of the ${ }^{40} \mathrm{~K}$ is weathered away.

Figure 6 shows a relation between the air absorbed dose rates obtained by subtracting the cosmic radiation from the dose rate measured by TLDs and the estimated doses by the concentrations of all the soil particles irrespective of their

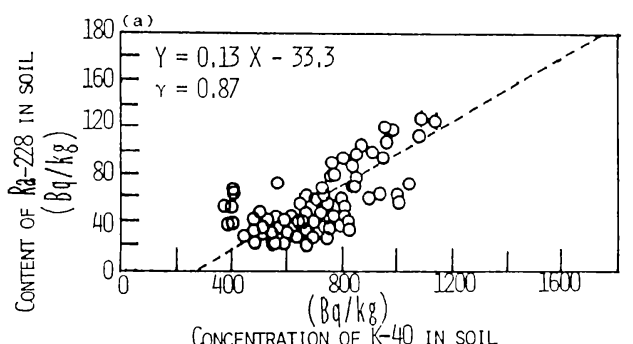

CONCENTRATION OF $K-40$ in SOIL

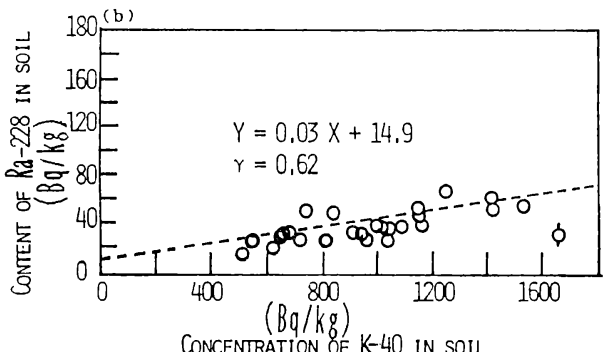

Fig. 5 The correlation between the concentration of ${ }^{40} \mathrm{~K}$ and ${ }^{228} \mathrm{Ra}$ in samples smaller than 10 mesh (a) and that larger than 10 mesh (b).

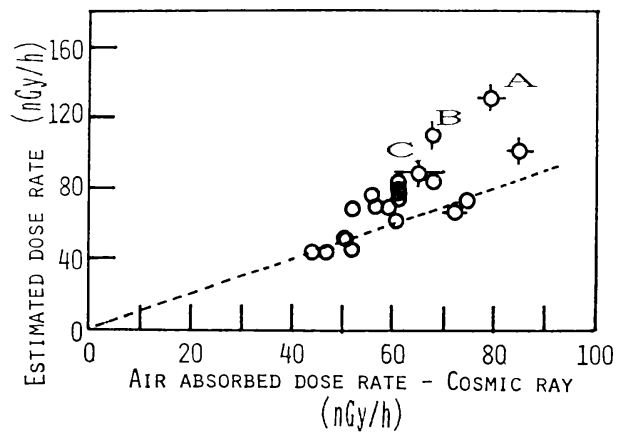

Fig. 6 The relation between the air absorbed dose rates obtained by subtracting the cosmic radiation from the TLD measurements and those estimated by Eq. (1) from the concentrations of ${ }^{238} \mathrm{U},{ }^{228} \mathrm{Ra}$ and ${ }^{40} \mathrm{~K}$ in all the samples irrespective of particle size.

size. As is shown, the rate, estimated from the whole samples are apparently close to the dose rates obtained by TLDs. However, some of the values estimated from the soils are higher than the dose rate obtained by TLDs. This can be explained as follows. The soils which had no stones larger than about $20 \mathrm{~mm}$ in diameter were collected as samples. While there were, in fact, some stones larger than about $20 \mathrm{~mm}$ in diameter in the ground, the dose estimated from the concentrations of the three nuclides in such stones 


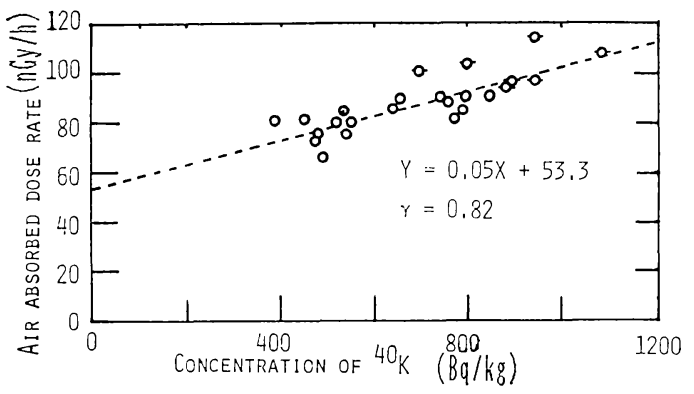

Fig. 7 A correlation between the air absorbed dose rates obtained by using TLDs and the concentration of ${ }^{40} \mathrm{~K}$ in all of the samples irrespective of particle size.

were smaller than that of collected soil samples. In addition, there were some buildings in the vicinity. Furthermore, the surface soils at sites named $\mathrm{A}, \mathrm{B}$ and $\mathrm{C}$ were carried from the granite zone when the school was built while the contents of ${ }^{238} \mathrm{U},{ }^{228} \mathrm{Ra}$ and ${ }^{40} \mathrm{~K}$ in the soil deeper than 10 $\mathrm{cm}$ are lower than that of the surface soil.

A good correlation between the absorbed dose rates in air and the ${ }^{40} \mathrm{~K}$ content in the soil was obtained as shown in Fig. 7. Then, we can roughly estimate the absorbed dose rate frcm the concentration of ${ }^{40} \mathrm{~K}$, that is easily obtainable, in the surface soil.

We estimated the population-weighted annual collective dose as $5,198 \mathrm{man} \cdot \mathrm{Sv} / \mathrm{y}$. This population-weighted annual collective dose is a little lower than $0.656 \times 10^{6} \mathrm{man} \cdot \mathrm{rad}(5,380 \mathrm{man} \cdot \mathrm{Sv})$ calculated by $\mathrm{S}$. ABE et al. ${ }^{2)}$ This is because we calculated the value by using the absorbed dose rate in air at all the 40 sites containing andesite zone having a low population density, while $\mathrm{S}$. ABE et al. ${ }^{1)}$ calculated the value from the absorbed dose rates in air in the area having rather high population density in the Osaka Pref.

\section{CONCLUSION}

We obtained the central value of absorbed dose rates in air in the Osaka Pref. to be $81.0 \pm 2.4$ $\mathrm{nGy} / \mathrm{h}$ by TLDs, and also obtained a fairly good correlation between the dose rates and concentrations of radionuclides in surface soils. It was found that the soil particles smaller than 10 mesh generally contribute more than that larger than 10 mesh to the dose rates, and it is anticipated that the dose rate can be estimated from concen- trations of ${ }^{40} \mathrm{~K}$ in surface soils.

ACKNOWLEDGMENT: The authors wish to express their thanks to Dr. T. Tsujimoto, Research React. Inst., Kyoto Univ. and Y. NAKASHIMA, Nagoya Univ. for their useful advice, and to Dr. H. MitsudA, Osaka City Univ. for measuring TLDs. We gratefully acknowledge their cooperations of 40 sites in Osaka Pref. A part of this work was supported by Osaka Nuclear Science Association.

\section{REFERENCES}

1) S. Abe, K. Fujitaka, M. Abe and K. Fujimoto; Extensive field survey of natural radiation in Japan, J. Nucl. Sci. Technol., 18 (1), 21 (1981).

2) K. Fujitaka, S. Abe and K. Fujimoto; Analysis of contour map of natural radiation in Japan, $J$. Nucl. Sci. Technol., 18 (9), 727 (1981).

3) F. Fujitaka, S. Abe and K. Fujmoto; Distribution of natural radiation in Japan in relation to geologic properties, J. Nucl. Sci. Technol., 18 (3), 222 (1981).

4) Editorial Committee of KINKI; "Regional Geology of Japan Part 6 KINKI," p. 41 (1988), Kyoritsu Shuppan, Tokyo.

5) K. Nakaseko and Y. Nakagawa; "Land classification map, subsurface geological map, Osaka Pref." (1973-1974), National Land Agency, Tokyo.

6) M. ICHIHARA; "Walking on the natural area around Osaka and Kobe," pp. 10-136 (1979), Sogensha, Osaka.

7) Geological Survey of Japan; "1:1,000,000 Geological Map of Japan-Geological Atlas of Japan (1982)-Second Printing (copy)," Geological Survey of Japan (1987), Tokyo.

8) Matsushita Electric and Industrial Company; "National Thermoluminescence Dosimetry," p. 10 (1982), Matsushita Electric and Industrial Company, Osaka.

9) M. Doi, K. Megumi, H. Ohta, Y. Nakashima and T. Ishiyama; Ann. Rep. Rad. Ctr. Osaka, 27, 23 (1986/1987).

10) K. Megumi and T. Mamuro; Concentration of uranium series nuclides in soil particles in relation to their sizes, J. Geophys. Res., 82 (2), 353 (1977).

11) National Institute of Radiological Science; "Natural Radiations in the Human Environment," T. Tsujmoro, Natural Radiation Exposure, p. 47 (1979), National Institute of Radiological Sciences, Chiba.

12) United Nations; "Report of United Nations 
Scientific Committee on the Effect of Atomic Radiations: Sources, Effects and Risks of Ionizing Radiation," p. 96 (1988), New York.

13) K. Megumi, S.H. Fan, S. Kimura, T. Tsujimoto,
T. Oka and K. Katsurayama; Concentration of Natural Radioactive Nuclides and Mineral Compositions in Soil in Relation to Their Sizes, Hoken Butsuri, 21, 155 (1985). 